\title{
İlkokullarda Görev Yapan Sınıf Öğretmenlerinin Eğitim Bilişim Ă̆ı (EBA) Kullanımlarının Öğretmen Görüşleri ile İncelenmesi
}

\author{
Investigation of Primary School Teachers Working in Educational Information Network (EBA) Using \\ Teacher Opinions
}

\author{
Salih SARIŞIK* (D), Sevilay SARIŞIK (iD), Derya AKAY CELEP iD, Mesut GÜREL ${ }^{\mathbb{D}}$, Salih DÖNMEZ (i)
}

\begin{abstract}
ÖZ
Amaç: Bu araștırmanın amacı, Millî Eğitim Bakanlığı’na bağlı ilkokullarda görev yapmakta olan sınıf öğretmenlerinin görüşlerine göre, ilkokullarda öğretmenlerin Eğitim Bilişim Ağını (EBA) kullanımının eğitim sürecine etkisini incelemektir. Bu amaç doğrultusunda; öğretmenlerin, eğitim bilişim ağını en fazla kullandığı dersler, uzaktan eğitim sürecinde derslerini yaparken eğitim bilişim ağı platformunu ne sıklıkla ve ne amaçla kullandıkları, ilkokullarda uygulanan uzaktan eğitim sürecinde eğitim bilişim ağı kullanımının öğrencilere ne tür fayda sağladığı, eğitim bilişim ağı kullanımında ne tür problemler ile karşılaştıkları, ilkokullarda kullanılan eğitim bilişim ağını geliştirmeye yönelik düşünceleri, eğitim bilişim ağı platformunda sevdikleri ve sevmedikleri yönlerin neler olduğu sorularına cevap aranmıştır.

Yöntem ve Araçlar: Araşıırmada nitel araştırma yöntemlerinden olgu bilim deseni kullanılmıştır. Araştırmanın çalışma grubunu Sakarya ili Sapanca ilçesi MEB ilkokullarda görev yapan 30 sınıf öğretmeni oluşturmaktadır. Araştırma verilerinin toplanmasında alan uzmanlarından faydalanılarak araştırmacı tarafından geliştirilen yarı yapılandırılmış görüşme formları kullanılmıştır. Elde edilen veriler betimsel analiz yöntemi ile çözümlenmiştir.

Sonuçlar: Araştırmadan elde edilen bulgular doğrultusunda; öğretmenlerin EBA’yı genellikle tüm derslerinde kullandığı, hafta içi uzaktan eğitim kapsamında canlı dersler için kullanmayı tercih ettiği, farklı kaynak desteği sağladığı için EBA sisteminin faydalı olduğu, EBA sisteminin kullanımında genellikle bağlantı sorunlarının yaşandığı ve bu sorunun giderilmesi için alt yapının iyileştirilmesi gerektiği, sistem içerisinde bulunan içeriğin ilkokul için yetersiz olduğu ve zenginleștirilmesi gerektiği, öğretmenlerin sistem ile ilgili sevdikleri özelliğin en çok öğrenciye ulaşmak ve çalışma göndermek olduğu, sevmedikleri özelliğin ise içerik kısmının ihtiyacı karşılamadığı şeklinde sonuçlara ulaşılmıştır.

Anahtar Kelimeler: İlkokul, Uzaktan Eğitim, Eğitim Bilişim Ağı.

ABSTRACT

Purpose: The purpose of this research is to examine the effect of teachers' use of the Educational Information Network (EBA) on the education process in primary schools, according to the opinions of primary school teachers working in primary schools affiliated to the Ministry of National Education in the Sapanca district of Sakarya province. In accordance with this purpose; the study looks into the courses in which the teachers use the educational information network the most, how often and for what purpose they use the educational information network platform while conducting their lessons in the distance education process, what kind of benefits the use of the educational information network provides to the students in the distance education process applied in primary schools, what kind of problems they encounter in the use of the educational information network, their opnions on developing the educational information network used in primary schools, and the aspects they liked and disliked in the educational information network platform.

Method and Materials: Phenomenology design, a qualitative research method, was used in the research. The study group of the research consists of 30 primary school teachers working in the MEB primary schools in the Sapanca district of Sakarya province. Semi-structured interview forms developed by the researcher were used in the collection of research data. The data obtained were analyzed by descriptive analysis method.

Results: According to the findings obtained from the research; teachers generally use EBA in all their lessons, prefer to use it for live lessons within the scope of distance education during the week, EBA system is useful because it provides different resource support, connection problems are often encountered in the use of the EBA system and the infrastructure needs to be improved to eliminate this problem. It was concluded that the content was found insufficient for primary school and should be enriched, that the most favorite feature of the system for teachers was to reach students and send tasks, and the feature they did not like was that the content did not meet the need.
\end{abstract}

Keywords: Primary school, Distance Learning, Education Information Network. 


\section{GİRIŞ}

Teknolojinin hızlı bir şekilde ilerlemesi ile birlikte dünya genelinde gözle görünür bir şekilde dönüşüm süreçleri yaşandığını bilinmektedir. Yaşanan bu süreçten en fazla etkilenen alanlar arasında hiç şüphesiz eğitim sistemi gelmektedir. Teknolojideki gelişmelerin insanlara sunduğu olanaklar ile okul ortamında kullanılan teknolojik materyaller giderek gelişmiş ve bu ortamlarda kullanılmıştır (Alabay, 2015). Bu gelişmeler Türkiye'de de etkisini göstermiştir. Teknolojinin sardığı dünyada yetişen çocuklar ve bu çocuklar ile teknolojiyle örülmüş bir sistem kurulmak hedeflenmiştir. Bu hedef Türkiye'de çeşitli projelerin geliştirilmesini yol açmıştır.

Türkiye'de oluşturulan projelerden son yıllarda yapılan çalışmalara bakıldığında Fırsatları Artırma ve Teknolojiyi İyileştirme Hareketi (FATİH) projesinin çok kapsamlı bir proje olduğu görülmektedir. Fatih Projesi okullara teknolojiyi getirerek eğitime entegre etmek için sisteme dahil edilmiştir (Milli Eğitim Bakanlığı [FATİH], 2018). Başlatılan bu hareketle okullara etkileşimli tahtalar entegre edilmiş ve öğrencilere akıllı tabletler dağıtılmıştır. Yapılan bu çalışmalar ile öğrencilerin teknolojiyi daha fazla kullanmalarının, öğrenmelerinde daha etkili olması düşülmüştür.

Okullara taşınan e-öğrenme biçimiyle birlikte etkileşimli tahtaların donanım ve yazılımsal alt yapısı da Fatih projesi kapsamında hazırlanmaktadır. Bu kapsamda hazırlanan yazılımsal içeriklerden biri de çevrimiçi dijital eğitim platformu olan Eğitim Biliş̧im Ağıdır (EBA). Eğitim Bilişim Ağı, Yenilik ve Eğitim Teknolojileri Genel Müdürlüğü (YEĞİTEK) tarafından yürütülmektedir ve ücretsiz olarak sunulmaktadır. Eğitim fırsatlarına herkesin eşit bir şekilde ulaşmasını sağlamak istenmektedir. Başta öğretmen ve öğrenciler olmak üzere tüm eğitim camiası için tasarlanan EBA, farklı materyal kullanımı desteklemek, eğitimdeki gelişmeleri takip ederek sürekli kendini güncellemek, öğrencilerin seviyelerine uygun içerikler sunmak, öğrenci farklılıklarını ön planda tutmak, zengin ders içerikleri sunmak, öğrencileri grup çalışmasına teşvik ederek iş birliğine yönlendirmek, ezbercilikten uzaklaşarak uygulamalı eğitim sistemine geçiş yapmak amacıyla hazırlanmıştır (EBA, 2019). Böylece eğitimin her birimine giren teknolojiyi kullanarak, özellikle yeni neslin akılcı, yorumlayan, bilgiyi kullanıp üretebilen bireyler olarak yetişmesi hedeflenmektedir (Yılmaz, 2007).

Milli Eğitim Bakanlığı’nın çok fazla önem verdiği FATİH projesi günümüze kadar etkili bir şekilde kullanılsa da içerisinde bulunulan Covid-19 salgın süreci ile Türk eğitim sistemine giren ve oldukça etkili olan uzaktan eğitim uygulamasında Eğitim Bilişim Ağı (EBA)'nın önemi daha da öne çıkmaktadır. Alanyazın incelendiğinde konu ile alakalı farklı çalışmalara ( Elçiçek, 2019; Demir, Özdinç ve Ünal, 2018; Özgümüş, 2018; Kana ve Aydın, 2017; Kalemkuş, 2016; Kurtdede Fidan, Erbasan ve Kolsuz, 2016; Alabay, 2015; Tutar, 2015; Güvendi, 2014; Özkan ve Deniz, 2014, Çiftçi, Taşkaya ve Alemdar, 2013; Ekici ve Yılmaz, 2013) rastlanılmaktadır.

\section{Araștırmanın Önemi}

Dünya genelinde hızla gelişen teknoloji her alanda olduğu eğitim alanında da etkisini göstermektedir. Öğretmenlerde diğer meslek gruplarında olduğu gibi mesleğe başladıktan sonraki dönemlerde teknolojinin etkisinde kendilerini sürekli geliştirmesi gerekmektedir. Özellikle öğretmenlerin bilgi ve iletişim teknolojilerine yönelik becerileri, teknolojiyi eğitimin içinde sürekli kullanması ve takip etmesi söylenebilir. İlkokullarda görev yapan öğretmenlerinin eğitim bilişim ağı (EBA) e-öğrenme ortamını ne seviyede bildiklerini, sistemi kullanma aralıklarını ve bu sisteme olan tutumları bu çalışmayı önemli hale getirmektedir. Bu çalışma dünyayı etkisi altına alan Covid-19 pandemisi döneminde ilkokul öğretmenlerinin Eğitim Bilişim Ağı (EBA) kullanımının eğitim sürecine etkisine yönelik öğretmen görüşlerini belirlemeyi amaçlamaktadır. Bu amaç ışığında araştırmada ilkokul öğretmenlerinin EBẢyı ne derecede bildiklerini, sistemi kullanma aralıklarını ve bu sisteme olan tutumlarını farklı görüşlerle değerlendirip tespit edilmesi amaçlanmıştır. Bu önemiyle çalışmanın ilkokul kademesinde eğitime ve eğitim bilişim ağı alanına katkı sağlayacağı düşünülmektedir. Ayrıca çalışmanın sonuçlarının eğitim bilişim ağı (EBA)'nın ilkokul kademesinde eğitim dönemindeki faaliyetlerin ve çalışmaların verimliliğine katkı sağlayacağı öngörülmektedir.

\section{Araştırmanın Amacı}

Eğitim bilişim ağı sistemini etkin bir şekilde kullanan öğretmenlerin bu öğrenme ortamı hakkındaki görüşleri, kullanabilme dereceleri, bu ortamın mevcut hali, yararlılığ önemlidir. Bu açıdan bakıldığında araştırmanın amacı, Millî Eğitim Bakanlığı’na bağlı ilkokullarda görev yapmakta olan sınıf öğretmenlerinin görüşlerine göre, ilkokullarda öğretmenlerin Eğitim Bilişim Ağını (EBA) kullanımının eğitim sürecine etkisini incelemektir. 


\section{Problem Cümlesi}

İlkokullarda görev yapan sınıf öğretmenlerinin EBA kullanımının eğitim öğretim sürecine etkisine yönelik görüşleri nelerdir?

\section{Alt Problemler}

1. Öğretmenlerin, eğitim bilişim ağını en fazla kullandığı ders hangisidir?

2. Öğretmenler, uzaktan eğitim sürecinde derslerini yaparken eğitim bilişim ağı platformunu ne sıklıkla ve ne amaçla kullanıyor?

3. İlkokullarda uygulanan uzaktan eğitim sürecinde eğitim bilişim ağı kullanımının öğrencilere sağladığı faydalar nelerdir?

4. Öğretmenlerin, eğitim bilişim ağı kullanımında karşılaştığı problemler nelerdir?

5. Öğretmenlerin, ilkokullarda kullanılan eğitim bilişim ağını geliştirmeye yönelik düşünceleri nelerdir?

6. Öğretmenlerin, eğitim bilişim ağı platformunda sevdikleri ve sevmedikleri yönleri nelerdir?

\section{YÖNTEM}

Bu bölümde araştırmanın modeli, çalışma grubu, ver toplama aracı, veri toplama ve analizleri hakkında bilgi verilmektedir.

\section{Araştırma modeli}

Araştırmada, ilkokullarda öğretmenlerin eğitim bilişim ağını (EBA) kullanımına yönelik öğretmen görüşlerinin alındığı̆, nitel araştırma yöntemlerinden olgu bilim deseni kullanılmıştır. Olgu bilim (fenomenoloji) deseni ile "farkında olduğumuz ancak derinlemesine ve ayrıntılı bir anlayışa sahip olmadığımız olgulara odaklanma" durumu ifade edilmektedir. Olgu bilim deseni ile yapılan araştırmalarda veriler toplanırken araştırmanın temelindeki olguyu yaşayan ve bu yaşanan olguyu dışa yansıtabilen kişiler belirlenmeli ve toplanan veriler analiz edilirken yaşantıları ve anlamları ortaya çıkarmaya yönelik olmalıdır şeklinde belirtilmiştir (Yıldırım ve Şimşek, 2011).

\section{Çalışma grubu}

Araştırmada, çalışma grubu Sakarya ili Sapanca ilçesinde görev yapan 30 sınıf öğretmeninden oluşmaktadır. Araştırmada çalışma grubunun oluşturulmasında farklı okullarda görev yapan sınıf öğretmenlerine ulaşarak çeşitlilik sağlanmıştır. Araştırmaya katılan sınıf öğretmenlerinin demografik bilgilerine ilişkin frekans ve yüzde dağılımları Tablo 1' de sunulmuştur.

Tablo 1: Katılımcıların Demografik Bilgilerine Ait Frekans ve Yüzde Dağılımları

$\begin{array}{llcc}\text { Özellikler } & & \mathrm{n} & \mathrm{f} \\ \text { Cinsiyet } & \text { Kadın } & 30 & 20 \\ \text { Mesleki deneyim } & \text { Erkek } & & 10 \\ & 1-10 \text { yıl } & 30 & 3 \\ & 11-20 \text { yıl } & & 13 \\ \text { Öğrenim durumu } & 21 \text { yıl ve üzeri } & 30 & 14 \\ \text { Yaş } & \text { Lisans } & 30 & 27 \\ & \text { Yüksek lisans } & & 3 \\ \text { Sinıf Seviyesi } & 20-30 \text { yaş arası } & 30 & 2 \\ & 30-40 \text { yaş arası } & & 10 \\ & 40 \text { ve üzeri } & & 18 \\ & 1 . \text { Sinıf } & 30 & 9 \\ \end{array}$


Tablo 1 incelendiğinde katılımcılardan (n=30) 20’si kadın ve 10’u erkek katılımcılardan oluşmaktadır. Ayrıca katılımcıların 18'nin 41 ve üzeri yaş arasında yoğunlaştığı görülmüştür. Katılımcıların öğrenim durumlarına bakıldığında 27 katılımcının lisans mezunu olduğu ve 3'ünün yüksek lisans eğitimlerini tamamladığı görülmektedir. Katılımcıların 12'sinin 3. sınıfı okutan sınıf öğretmenlerinden oluştuğu görülmektedir.

\section{Veri toplama araci}

Araştırmada veri toplama aracı olarak görüşme formu kullanılmıştır. Görüşme sorularının hazırlık aşamasında literatür incelenerek ilgili alt problemleri en iyi şekilde ifade edecek 6 adet açık uçlu soru araştırmacı tarafından hazırlanarak görüşme formuna yazılmıştır. Açık uçlu araştırma soruları "araştırmacıya incelemek istediği olguya esnek ve açık uçlu bir yaklaşımla ele alma olanağı sağlar” (Yıldırım ve Şimşek, 2008).

Öğretmenler için hazırlanan yarı yapılandırılmış görüşme formunu incelemek üzere 2 ayrı uzman görüşüne başvurulmuş ve uzman görüşleri doğrultusunda forma son şekli verilmiştir. Görüşmeler, okullarda öğretmenlerin uygun olduğu zamanlarda gerçekleştirilmiştir. Yapılan görüşme sırasında öğretmenler kendilerine sorulan 6 sorunun tamamına cevap vermiş ve fikirlerini söylemişlerdir.

\section{Verilerin analizi}

Araştırma sonucunda görüşmelerde ulaşılan verilerin analizinde, içerik analizi ile betimsel analiz yöntemleri kullanılmıştır. Frekans (f) değerleri hesaplanarak tabloda belirtilmiştir. Betimsel analizde veriler kategorize edilirken daha önce belirlenen çerçeveye uygun olmasına dikkat edilmektedir. Çerçevenin oluşmasında görüşme soruları kullanılabilir. İçerik analizi sonucunda ulaşılan veriler ise kodlanarak kategorileri/temaları oluşturmaktadır (Yıldırım ve Şimşek, 2008). Örneğin araştırmada eğitim bilişim ağının en fazla kullanıldığı derse ilişkin görüşleri belirlenirken ifade edilen görüşler, tüm dersler, Türkçe, Hayat Bilgisi ve Matematik olarak kodlanmış, bu kodlardan hareketle “ eğitim bilişim ağının en fazla kullanıldığı dersler " teması oluşturulmuş ve elde edilen veriler bu tema çerçevesinde tablo halinde gösterilmiştir. Doğrudan alıntı yapılan öğretmenler Ö1,Ö2 ........̈30 şeklinde belirtilmiştir.

\section{BULGULAR}

Eğitim bilişim ağının (EBA) en fazla kullanıldığı derse ilişkin öğretmen görüşleri tablo 2'de sunulmuştur.

Tablo 2: Eğitim Bilişim Ağının (EBA) En Fazla Kullanıldı̆̆ı Derse İlişkin Öğretmen Görüşleri

\begin{tabular}{|c|c|c|c|c|}
\hline Tema (Kategoriler) & Kodlar & $\mathrm{n}$ & $\mathrm{f}$ & $\%$ \\
\hline \multirow{4}{*}{$\begin{array}{l}\text { Eğitim bilişim ağının en fazla } \\
\text { kullanıldığı dersler }\end{array}$} & Tüm dersler & 30 & 13 & 43.4 \\
\hline & Türkçe & 30 & 9 & 30.0 \\
\hline & Hayat bilgisi & 30 & 4 & 13.3 \\
\hline & Matematik & 30 & 4 & 13.3 \\
\hline
\end{tabular}

Tablo 2 incelendiğinde eğitim bilişim ağının (EBA) en fazla kullanıldığ derse ilişkin öğretmen görüşleri en çok \% 43.4 oranında tüm dersler şeklinde olduğu görülmüştür. Diğer görüşler sırayla, \% 30.0 oranında Türkçe, \% 13.3 oranında hayat bilgisi ve matematik yer almaktadır. Öğretmenlerin görüşlerinden alınan birebir alıntılar aşağıda sunulmaktadir.

$\ddot{O}_{l}:$ :Hepsinde kullaniyorum. Türkçe, Matematik, Hayat Bilgisi, Görsel Sanatlar, Müzik, Beden Ĕgitimi ve oyun derslerinde"

$\ddot{O}_{3}:$ "Genellikle Türkçe dersinde kullanıyorum."

$\ddot{O}_{17}:$ "Hayat Bilgisi dersinde kullaniyorum."

$\ddot{O}_{25}:$ "Matematik dersinde kullanmay tercih ediyorum."

Uzaktan eğitim sürecinde eğitim bilişim ağının (EBA) hangi amaçla ve ne sıklıkla kullanıldığına ilişkin öğretmen görüşleri tablo 3 'de sunulmuştur. 
Tablo 3: Uzaktan Eğitim Sürecinde Eğitim Bilişim Ağının (EBA) Hangi Amaçla ve Ne Sıklıkla Kullanıldığına İlişkin Öğretmen Görüşleri

\begin{tabular}{|c|c|c|c|c|}
\hline Tema (Kategoriler) & Kodlar & $\mathrm{n}$ & f & $\%$ \\
\hline \multirow{2}{*}{$\begin{array}{l}\text { EBA'nın hangi sıklıkla } \\
\text { kullanıldığ } 1\end{array}$} & Hafta içi (5 gün) & 30 & 19 & 63.4 \\
\hline & Her gün (7 gün) & 30 & 11 & 36.6 \\
\hline \multirow{2}{*}{$\begin{array}{l}\text { EBA'nın hangi amaçla } \\
\text { kullanıldığ } 1\end{array}$} & Canlı ders için & 30 & 20 & 66.6 \\
\hline & Ödev için & 30 & 10 & 33.4 \\
\hline
\end{tabular}

Tablo 3 incelendiğinde uzaktan eğitim sürecinde eğitim bilişim ağının (EBA) hangi amaçla ve ne sıklıkla kullanıldığına ilişkin öğretmen görüşleri en çok \% 63.4 oranında hafta içi ve \% 66.6 oranında canlı ders için şeklinde olduğu görülmüştür. Diğer görüşler, \% 36.6 oranında her gün ve \% 33.4 oranında ödev için şeklindedir. Öğretmenlerin görüşlerinden alınan birebir alıntılar aşağıda sunulmaktadır.

$\ddot{O}_{18}:$ "Hafta içi her gün canlı derslerimde kullanıyorum Hafta içi ve hafta sonları eba üzerinden çalışmalar göndererek ögrencileri ödevlendiriyorum.”

$\ddot{O}_{4}$ : "Günlük kullaniyorum. Ödev vermek, ödevleri incelemek için"

$\ddot{O}_{23}:$ "Her gün temel derslerdeki konu anlatımlarl, canlı dersler için kullanıyorum."

İlkokullarda uygulanan uzaktan eğitim sürecinde eğitim bilişim ağı kullanımının öğrencilere sağladığı faydalara ilişkin öğretmen görüşleri tablo 4'de sunulmuştur.

Tablo 4: İlkokullarda Uygulanan Uzaktan Eğitim Sürecinde Eğitim Bilişim Ağı (EBA) Kullanımının Öğrencilere Sağladığı Faydalara İlişkin Öğretmen Görüşleri

\begin{tabular}{llccc} 
Tema (Kategoriler) & Kodlar & $\mathrm{n}$ & $\mathrm{f}$ & $\%$ \\
Evet, fayda sağlıyor. & $\begin{array}{l}\text { Zengin içerikle kaynak } \\
\text { desteği sağlıor }\end{array}$ & 30 & 14 & 46.6 \\
& $\begin{array}{l}\text { Motive ediyor ve } \\
\text { eğlendiriyor }\end{array}$ & 30 & 12 & 40.0 \\
\hline Hayır, fayda sağlamıyor & $\begin{array}{l}\text { Yeterli içeriğe sahip } \\
\text { değil }\end{array}$ & 30 & 4 & 13.4 \\
\hline
\end{tabular}

Tablo 4 incelendiğinde ilkokullarda uygulanan uzaktan eğitim sürecinde eğitim bilişim ağı kullanımının öğrencilere sağladığı faydalara ilişkin öğretmen görüşleri en çok \% 86.6 oranında fayda sağlıyor ve bu faydalar \% 46.6 oranında zengin içerikle kaynak desteği ve \% 40.0 oranında motive ediyor ve eğlendiriyor şeklinde olduğu görülmüştür. Diğer görüşler ise, \% 13.4 oranında yeterli içeriğe sahip olmadığı için fayda sağlamıyor şeklindedir. Öğretmenlerin görüşlerinden alınan birebir alıntılar aşağıda sunulmaktadır.

$\ddot{O}_{9}:$ "EBA kullanımının öğrencilere fayda sağladığını düşünüyorum. Yüz yüze yapılan eğitim ile karşılaştırıldığında daha fazla görsel ve işitsel kaynak içermesi ve istenilen kaynağa anında ulaşım sağlaması öğrenmenin kalıcılığını artırmaktadir."

$\ddot{O}_{27}$ : "Fayda sağladığını düşünüyorum. Çünkü ben ders anlattıktan sonra çocuklara videoları ve testleri yaptırlyorum. Bu durum onları hem eğlendiriyor hem de motive ediyor diye düşünüyorum."

$\ddot{O}_{6}:$ "Hayır, ilkokul öğrencilerine yönelik zengin içeriğin olmayışından dolayı çok fazda sağladĭ̆ını düşünmüyorum."

Uzaktan eğitim sürecinde eğitim bilişim ağının (EBA) kullanımında karşılaşılan sorunlar ve sorunlara ilişkin öneriler ile ilgili öğretmen görüşleri tablo 5'de sunulmuştur.

Tablo 5: Uzaktan Eğitim Sürecinde Eğitim Biliş̧im Ağının (EBA) Kullanımında Karşılaşılan Sorunlar ve Sorunlara İlişkin Öneriler ile İlgili Öğretmen Görüşleri

\begin{tabular}{lllcc} 
Tema (Kategoriler) & Kodlar & $\mathrm{n}$ & $\mathrm{f}$ & \multicolumn{1}{c}{$\%$} \\
EBA kullanımında & Bağlantı ve alt yapı sorunu & 30 & 23 & 76.6 \\
\cline { 2 - 5 } karşılaşılan sorunlar & İcriğin yetersiz olması & 30 & 5 & 16.6 \\
\cline { 2 - 5 } & Velilerin ilgisizliği ve ekonomik durumu & 30 & 2 & 6.8 \\
\hline
\end{tabular}




\begin{tabular}{|c|c|c|c|c|}
\hline \multirow{4}{*}{$\begin{array}{l}\text { EBA kullanımında } \\
\text { karşılaşılan sorunlara } \\
\text { ilişkin çözüm önerileri }\end{array}$} & Bağlantı ve alt yapı sorunun giderilmesi & 30 & 16 & 53.3 \\
\hline & İçeriğin zenginleştirilmesi & 30 & 5 & 16.6 \\
\hline & $\begin{array}{l}\text { Veliler bilinçlendirilmeli ve maddi } \\
\text { destek verilmeli }\end{array}$ & 30 & 5 & 16.6 \\
\hline & Ders saati tanımlaması düzeltilmeli & 30 & 4 & 13.5 \\
\hline
\end{tabular}

Tablo 5 incelendiğinde uzaktan eğitim sürecinde eğitim bilişim ağının (EBA) kullanımında karşılaşılan sorunlar ve sorunlara ilişkin öneriler ile ilgili öğretmen görüşleri en çok \% 76.6 oranında bağlantı ve alt yapı sorunu, öneri olarak \% 53.3 oranında bağlantı ve alt yapı sorununun giderilmesi şeklinde olduğu görülmüştür. Diğer sorunlar görüşleri sırayla, \% 16.6 içeriğin yetersiz olması ve \% 6.8 oranında velilerin ilgisizliği ve ekonomik sorunlar şeklindedir. Diğer öneri görüşleri sırasıyla, \% 16.6 oranında içerik zenginleştirilmeli ve veliler bilinçlendirilmeli ve maddi destek verilmeli, \% 13.5 oranında ders saati tanımlaması düzenlenmesi görüşleri yer almaktadır. Öğretmenlerin görüşlerinden alınan birebir alıntılar aşağıda sunulmaktadır.

$\ddot{O}_{16}:$ "Oldukça yavaş, kesintiler çok fazla oluyor. Alt yapı yetersizliği ve bağlantı sorunu giderilmelidir."

$\ddot{O}_{15}:$ "İlkokul içeriğinin yetersiz olduğunu düşünüyorum Test, ödev, konu anlatımı ve video gibi etkinlikler artırlmalıdır."

$\ddot{O}_{8}:$ "Veliler eğitimli olmalı ve ekonomik durumu gerekli ekipmanlar için yeterli olmall. Ayrlca veliler uzaktan eğitim konusunda bilinçli olmall, veli eğitimine önem verilmelidir.”

$\ddot{O}_{2}:$ "Sisteme aşır yüklenme olduğunda sitenin bunu kaldıramamasından dolayı derslere zamanında başlayamıyorum. Ayrıca ders saati dilimleri serbest olmall."

Uzaktan eğitim sürecine öğrencilerin tam katılım sağlayamama durumlarına ilişkin öğretmen görüşleri tablo 6'da sunulmuştur.

Tablo 6: Uzaktan Eğitim Sürecine Öğrencilerin Tam Katılım Sağlayamama Durumlarına İlişkin Öğretmen Görüşleri

\begin{tabular}{llccc} 
Tema (Kategoriler) & Kodlar & $\mathrm{n}$ & $\mathrm{f}$ & $\mathrm{\%}$ \\
\begin{tabular}{l} 
Uzaktan eğitime tam katılım \\
\multirow{2}{*}{$\begin{array}{l}\text { sağlayamama durumları } \\
\text { İnernet ve bağlantı problemi }\end{array}$}
\end{tabular} & 30 & 17 & 56.6 \\
\cline { 2 - 5 } & yaşamaları & 30 & 8 & 26.6 \\
\cline { 2 - 5 } & Ekelerin ilgisizliği & 30 & 5 & 16.6 \\
\hline
\end{tabular}

Tablo 6 incelendiğinde uzaktan eğitim sürecine tam katılım sağlayamama durumlarına yönelik öğretmen görüşleri en çok \% 56.6 oranında internet ve bağlantı problemi şeklinde olduğu görülmüştür. Diğer görüşler sırayla, \% 26.6 oranında aile ilgisizliği ve \% 16.6 oranında ekonomik nedenler yer almaktadır. Öğretmenlerin görüşlerinden alınan birebir alıntılar aşağıda sunulmaktadır.

$\ddot{O}_{I}:$ "Uzaktan eğitimlere katılamayan ögrencilerin en büyük problemi internet ve bağlantı problemidir. Bu problem sadece bizim ögrencilerimizin değil Türkiye genelinde büyük bir sorundur diye düşünüyorum.”

$\ddot{O}_{18}:$ "Bazı ailelerin bu konuda ilgisiz davrandı̆̆ını düşünüyorum."

$\ddot{O}_{21}:$ "Öğrencilerin bir klsmının okula giden kardeşinin olması, bilgisayar, tablet, telefon vs. teknolojik aletlerin temin edilememesi gibi sorunlar aile ekonomisinden kaynaklandiğını düşünüyorum.

Araştırmaya katılan öğretmenlerin Covid-19 sürecindeki uzaktan eğitim ile ilgili ifade ettikleri öneriler tablo 7'de sunulmuştur.

Tablo 7: Öğretmenlerin Covid-19 Sürecindeki Uzaktan Eğitime İlişkin Önerileri

\begin{tabular}{|c|c|c|c|c|c|}
\hline Tema (Kategoriler) & & Kodlar & $\mathrm{n}$ & f & $\%$ \\
\hline \multirow{4}{*}{$\begin{array}{l}\text { Uzaktan eğitime } \\
\text { öğretmen önerileri }\end{array}$} & \multirow{4}{*}{ yönelik } & Alt yapıya ilişkin öneriler & 30 & 15 & 50.0 \\
\hline & & Planlamaya ilişkin öneriler & 30 & 8 & 26.6 \\
\hline & & İçeriğe ilişkin öneriler & 30 & 5 & 16.6 \\
\hline & & Uygulamaya ilişkin öneriler & 30 & 2 & 6.6 \\
\hline
\end{tabular}

Tablo 7 incelendiğinde öğretmenlerin covid-19 sürecindeki uzaktan eğitime ilişkin görüşleri en çok \% 50.0 oranında altyapıya ilişkin öneriler şeklinde olduğu görülmüştür. Diğer öneriler sırayla, \% 26.6 planlamaya ilişkin öneriler, \% 
16.6 oranında içeriğe ilişkin öneriler ve \% 6.6 oranında uygulamaya ilişkin öneriler yer almaktadır. Öğretmenlerin önerilerinden alınan birebir alıntılar aşağıda sunulmaktadır.

$\ddot{O}_{2}:$ "Uygulanan uzaktan eğitimlerin daha faydalı ve kalıcı olması için altyapı ve bağlantı sorunlarının giderilmesi ve iyileştirilmesi gerektiğini düşünüyorum."

$\ddot{O}_{5}:$ "Uzaktan eğitim kapsamında yapılan canlı derslerin, sabah saatleri dışında öğlen saatlerinde yapılması ve ders süresinin kısaltılması gerektiğini düşünüyorum."

$\ddot{O}_{7}:$ "TRT EBA tv kapsam olarak genişletilebilir. Ayrıca Türkiye genelinde aynı kaynakların kullanılması lazım bence."

$\ddot{O}_{19}:$ "Canlı dersleri okullarımıza gidip sınıf ortamında yapmalıyı. Böylelikle hem öğrenci derse daha aktif katılır, hem ögretmen dersine daha iyi hazırlanir."

\section{SONUÇ VE TARTIŞMA}

Eğitim bilişim ağının (EBA) en fazla kullanıldığı derse ilişkin sınıf öğretmenlerinin görüşlerine yönelik sonuçlar.

Çalışmaya katılan sınıf öğretmenlerinin görüşlerine göre, EBA’nın bütün derslerde kullanıldı̆̆ı sonucu ortaya çıkmıştır. Kurtdede, Fidan, Erbasan ve Kolsuz (2016) tarafından gerçekleştirilen sınıf öğretmenlerinin eğitim bilişim ağı’ndan (eba) yararlanmaya ilişkin görüşleri ile ilgili bir çalışmada, sınıf öğretmenlerinin EBA' yı sıklıkla kullanmadıkları sonucuna ulaşılmıştır. Sıklıkla kullanmamalarına rağmen sınıf öğretmenleri EBA’ nın kullanışlı ve faydalı bir platform olduğunu belirtmişlerdir. Bu nedenle covid-19 pandemi sürecinde sınıf öğretmenleri uzaktan eğitim esnasında eğitim bilişim ağını tercih etmişlerdir. Bu durum çalışmayı destekler yöndedir.

Uzaktan eğitim sürecinde eğitim bilişim ağının (EBA) hangi amaçla ve ne sıklıkla kullanıldığına ilişsin sınıf öğretmenlerinin görüşlerine yönelik sonuçlar.

Çalışmaya katılan sınıf öğretmenlerinin görüşlerine göre, EBA’nın hafta içi her gün uzaktan eğitim amacıyla canlı ders uygulanmasını kullanıldığı sonucu ortaya çıkmıştır. Covid-19 pandemisinden kaynaklanan derslerin uzaktan eğitim şeklinde yapılmasının çeşitli sonuçları olmuştur. Uygulanan uzaktan eğitimin yüz yüze eğitimin yerini tutmadığı öğretmenler tarafından belirtilse de tüm dünyayı etkisi altına alan pandemi sürecinde en etkili yöntemin uzaktan eğitim yoluyla yapıldığı görüşü bilinmektedir. Sindiani ve ark. (2020) de yapmış oldukları araştırmalarında covid-19 pandemi sürecinde uygulanan uzaktan eğitimin en verimli ve tercih edilen bir sistem olduğu sonucuna ulaşmışlardır. Öğretmenler Eğitim Bilişim Ağı (EBA) üzerinden uzaktan eğitim amaçlı yapılan canlı dersleri yeterli bulmadıklarını belirtmişler ancak öğrencilerin derslerden uzak kalmamaları, okul ortamından ayrı kalmamaları ve bu süreci tatil gibi değerlendirmemeleri amacıyla hafta içi belirli saatlerde kullanmışlardır.

İlkokullarda uygulanan uzaktan eğitim sürecinde eğitim bilişim ağı kullanımının öğrencilere sağladığı faydalara ilişkin sınıf öğretmenlerinin görüş̧lerine yönelik sonuçlar.

Çalışmaya katılan sınıf öğretmenlerinin görüşlerine göre, EBA’nın sağladığı zengin içerikler sayesinde öğrencilere farklı kaynak imkânı sunduğu ve bu yönüyle faydalı olduğu sonucu ortaya çıkmıştır. Çiftçi, Taşkaya ve Alemdar (2013) sınıf öğretmenlerinin FATİH projesine ilişkin görüşlerini incelediği çalışmalarında, Eğitim Bilişim Ağının (EBA) faydaları konusunda sınıf öğretmenlerin, görsel kaynaklar ile öğrenmeyi desteklediği ve bilgiye erişmenin daha hızlı olduğu sonucuna ulaşmışlardır. Altuntaş Yüksel (2021) Sınıf öğretmenlerinin covid-19 salgını sürecinde uzaktan eğitim deneyimlerinin incelenmesi ile ilgili yaptığı çalışmasında, uzaktan eğitim sürecinin zaman ve mekândan tasarruf sağladığını, hareketliliği azaltarak salgından korunmayı kolaylaştırdığı şeklinde yararlar sağladığı sonucuna ulaşılmıştır. Bu sonuçlar çalışmanın sonucu ile benzerlik göstermektedir.

Uzaktan eğitim sürecinde eğitim bilişim ağının (EBA) kullanımında karşılaşılan sorunlar ve sorunlara ilişkin öneriler ile ilgili sınıf öğretmenlerinin görüşlerine yönelik sonuçlar.

Çalışmaya katılan sınıf öğretmenlerinin görüşlerine göre, EBA’ nın kullanımı sırasında en çok bağlantı ve alt yapı sorunu yaşandığı ve soruna çözüm önerisi olarak yaşanan bağlantı ve alt yapı probleminin giderilmesi gerektiği sonuçları ortaya çıkmıştır. Kana ve Aydın (2017) tarafından ortaokul öğretmenleri ve öğrencilerinin EBA hakkındaki görüşlerini incelemek amacı ile yapılan araştırmada, öğretmenlerin EBA sistemine erişim sağlarken karşılaştıkları en büyük sıkıntının bağlantıdan kaynaklandığı sonucuna ulaşmışlardır. Türker ve Güven (2016) lise öğretmenlerinin 
eğitim bilişim ağı (EBA) projesinden yararlanma düzeyleri ve proje ile ilgili görüşleri hakkındaki yaptıkları çalışmada, öğretmenlerin ve öğrencilerin internet bağlantısından kaynaklanan sorunlar nedeni ile EBA sistemini verimli bir şekilde kullanamadıklarını ve sisteme istedikleri zamanlarda erişim sağlayamadıklarını sonucuna ulaşmışlardır. Kalemkuş (2016) ortaöğretimdeki öğretmen ve öğrencilerin eğitim bilişim ağı (EBA)'ya ilişkin görüşlerini incelemek amacı ile yapmış olduğu çalışmasında, teknik anlamda altyapı sorunlarının çözümü noktasında konunun uzmanı elemanlar kullanılarak hızlı müdahale ve iyileştirmelerle sistemin kullanım oranının artacağını ve yaşanan sorunların giderileceği belirtmiştir. Bu sonuçlar çalışmayı desteklemektedir.

Öğrencilerin uzaktan eğitim sürecine tam katılım sağlayamama durumları ile ilgili sonuçlar.

Çalışmaya katılan sınıf öğretmenlerinin görüşlerine göre, öğrencilerin uzaktan eğitim sürecine tam katılım sağlayamama durumu olarak en çok internet ve bağlantı problemleri yaşandığı ve ailelerin bu konuda ilgisiz davrandığı sonucu ortaya çıkmaktadır. Demir ve Özdaş (2020) covid-19 sürecindeki uzaktan eğitime ilişkin öğretmenler ile yaptıkları çalışmalarında, uygulanan uzak eğitim faaliyetlerinde öğrencilerin genellikle altyapı, eğitime katılım ve EBA sistemi ile ilgili sorunların görüldügü sonucuna ulaşmışlardır. Canpolat ve Yıldırım (2021) ortaokul öğretmenlerinin covid-19 salgın sürecinde uzaktan eğitim deneyimlerini incelediği çalışmalarında, internete erişimi olmayan öğrencilerin uzaktan eğitim çalışmalarından faydalanamadığı sonucuna ulaşmışlardır. Bu sonuçlar araştırmanın bulgusu ile benzerlik göstermektedir.

Öğretmenlerin covid - 19 sürecinde uygulanan uzaktan eğitim faaliyetlerine ilişkin önerileri.

Çalışmaya katılan sınıf öğretmenleri covid-19 sürecinde uygulanan uzaktan eğitim faaliyetleri ile ilgili alt yapıya ilişkin, planlamaya ilişkin, sunulan içeriğe ilişkin ve EBA uygulamasına ilişkin önerilerde bulunmuşlardır.

\section{ÖNERILER}

\section{Araştırma sonuçlarına dayalı öneriler}

- Uzaktan eğitim ile yapılan ders içi ve ders dışı etkinliklere ve canlı derslere ilkokul öğrencilerin ve öğretmenlerin teknik bağlantı sorunlarının ve internet ihtiyaçlarının giderilmesi gerekmektedir.

- İlkokul kademesinde öğrencileri olan velilere uzaktan eğitim süreci ve eğitim bilişim ağı (EBA) kullanımı ile ilgili eğitimler verilebilir.

- Uzaktan eğitim yolu ile yapılan canlı derslere öğrenci katılımının daha yüksek oranlarda olması için öğrencileri teşvik edici puanlama, rozet ya da puanlama gibi ödüllendirmeler yapılabilir.

\section{Gelecek araştırmalara yönelik öneriler}

- Bu çalışmada sadece görüşme formu ile toplanan veriler incelenmiştir. İlerde yapılacak çalışmalarda görüşme formunun yanında anket uygulaması ve gözlem gibi teknikler kullanılarak daha kapsamlı çalışmalarla alan yazına katkıda bulunulabilir.

- Bu araştırma sadece ilkokul öğretmenleri ile yapılmıştır. Ortaokul ve lise gibi farklı öğretim kademelerinde de görev yapan diğer branş öğretmenleri ile de pandemi döneminde uzaktan eğitim uygulamaları ile ilgili benzer çalışmalar yapılabilir.

- Eğitim Bilişim Ağı (EBA) kullanımı ile ilgili çalışmamızda çalışma grubumuzu sadece ilkokullarda görev yapan sınıf öğretmenleri oluşturmaktadır. Benzer çalışmalarda ilkokul idarecileri ve velileri çalışma grubuna eklenebilir.

\section{KAYNAKÇA}

Alabay, A. (2015). Ortä̈ğretim öğretmenlerinin ve öğrencilerinin eba (Eğitimde Bilişim Ağı) kullanımına ilişkin görüşleri üzerine bir araştırma (Yayımlanmamış yüksek lisans tezi). İstanbul Aydın Üniversitesi Sosyal Bilimler Enstitüsü, İstanbul.

Altıntaş Yüksel, E. (2021). Sınıf öğretmenlerinin covid-19 salgını sürecinde çevrim içi ders-uzaktan eğitim deneyimlerinin 
incelenmesi. Ulakbilge, 57 (2021 Şubat): s. 291-303.

Canpolat, U. ve Yıldırım, Y. (2021). Ortaokul öğretmenlerinin Covid-19 salgın sürecinde uzaktan eğitim deneyimlerinin incelenmesi. Açık öğretim Uygulamaları ve Araştırmaları Dergisi, 7 (1) ,74-109.

Çiftçi, S., Taşkaya, S.M. ve Alemdar, M. (2013). Sınıf öğretmenlerinin fatih projesine ilişsin görüşleri. İlköğretim Online, 12(1), s. 227-240.

Demir, D., Özdinç, F., ve Ünal, E. (2018). Eğitim bilişim ağı (EBA) portalına katılımın incelenmesi (Siirt İli Örneği). Erzincan Üniversitesi Ĕ̈itim Fakültesi Dergisi , 20 (2), 2148-7510.

Demir, F. ve Özdaş, F. (2020). Covid-19 sürecindeki uzaktan eğitime ilişkin öğretmen görüşlerinin incelenmesi. Milli Eğitim Dergisi, Salgın Sürecinde Türkiye’de ve Dünyada Eğitim, 273-292.

Eğitim Bilişim A $\breve{g}$ (EBA), (2019). https://www.eba.gov.tr/haber/156.811.2949 adresinden 05.02.2021 tarihinde erişilmiştir.

Ekici, S. ve Yılmaz, B. (2013). Fatih projesi üzerine bir değerlendirme. Türk Kütüphaneciliği Dergisi, 27(2), s. 317-339.

Elçiçek, A. (2019). Eğitim bilişim ă̆ı (EBA) web sitesinin öğretmenler tarafından kullanım sıklğının incelenmesi (Yüksek lisans tezi). Mardin İli Kızıltepe İlçesi Örneği.

Güvendi, G. M. (2014). Millî Eğitim Bakanlı̆̆ı’nın öğretmenlere sunmuş olduğu çevrimiçi eğitim ve paylaşım sitelerinin öğretmenlerce

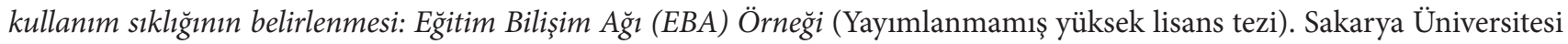
Eğitim Bilimleri Entitüsü, Sakarya.

Kalemkuş, F. (2016). Ortaöğretimdeki öğretmen ve öğrencilerin eğitim bilişim ăğ (EBA)’ya ilişkin görüşleri (Yüksek lisans tezi). Afyon Kocatepe Üniversitesi, Fen Bilimleri Enstitüsü, Afyonkarahisar.

Kana, F. ve Aydın, V. (2017). Ortaokul öğretmenleri ve öğrencilerinin eğitim bilişim ağı hakkında görüşleri. Journal Of Social And Humanities Sciences Research (Jshsr), Vol:4, Issue:13, 1494-1504.

Kurtdede Fidan, N., Erbasan, Ö. ve Kolsuz, S. (2016). Sınıf öğretmenlerinin eğitim bilişim ağı’ndan (eba) yararlanmaya ilişkin görüşleri. Uluslararası Sosyal Araştırmalar Dergisi, 9(45), 626-637.

Milli Eğitim Bakanlığı Fatih, (2018). Fatih Projesi. http://fatihprojesi.meb.gov.tr/about.html adresinden 1 Aralık 2018 tarihinde erişildi.

Özgümüş, Ö. (2018). Bursa ilinde öğrenci-veli-öğretmenlerin eğitim bilişim ağının (EBA) kullanım sıklı̆̆ının belirlenmesi (Yayınlanmamış yüksek lisans tezi). Uludağ Üniversitesi Eğitim Bilimleri Enstitüsü, Bursa

Özkan, A. ve Deniz, D. (2014). Orta öğretimde görev yapan öğretmenlerin fatih projesine ilişkin görüşleri. Ege Eğitim Dergisi, 15(1), s. 161-175.

Sindiani, A.M., Obeidat, N., Alshdaifat, E., Elsalem, L., Alwani, M., Rawashdeh, H., Fares, A., Alalawne, T. ve Tawalbeh, L. İ. (2020). Distance education during the COVID-19 outbreak: A cross-sectional study among medical students in North of Jordan. Annals of Medicine and Surgery, 59, 186- 194.

Tutar, M. (2015). Eğitim bilişim ağı (Eba) sitesine yönelik olarak öğretmenlerin görüşlerinin değerlendirilmesi ( Yayımlanmamış yüksek lisans tezi ). Karadeniz Teknik Üniversitesi Eğitim Bilimleri Enstitüsü, Trabzon.

Türker, A. ve Güven, C. (2016). Lise öğretmenlerinin eğitim bilişim ağ (EBA) projesinden yararlanma düzeyleri ve proje ile ilgili görüşleri. Eğitim ve Öğretim Araştırmaları Dergisi, 5/1, 244-254.

Yıldırım, A. ve Şimşek, H. (2008). Sosyal bilimlerde nitel araştırma yöntemleri. Ankara: Seçkin Yayıncılık.

Yılmaz, M. (2007). Sınıf öğretmeni yetiştirmede teknoloji eğitimi. Gazi Eğitim Fakültesi Dergisi, Cilt 27, Sayı 1(2007) $155-167$. 


\title{
Investigation of Primary School Teachers Working in Educational Information Network (EBA) Using Teacher Opinions
}

\author{
Salih SARIŞIK (iD), Sevilay SARIŞIK (iD), Derya AKAY CELEP (iD), Mesut GÜREL (iD), Salih DÖNMEZ (D)
}

\section{Introduction and purpose}

It is considered that with the rapid developments in technology, there are noticeable transformation processes taking place throughout the world. The education system is undoubtedly one of the most affected areas by this process. These transformations have also had an impact on Turkey. It has been aimed to establish a technology-based system for children growing up with technology. This goal has led to the development of various projects in Turkey.

The Fatih project is the most comprehensive of the projects created in Turkey in recent years. Upon this project, it was aimed to bring technology to all schools by providing equality in education (Ministry of Education Fatih [FATIH], 2018). As part of this project, the use of interactive whiteboards in schools has begun and smart tablets have been distributed to students. It was thought that e-learning would be integrated into education quickly and easily with these applied methods.

The opinions of teachers using the educational information network system effectively about this learning environment and the degree of their ability to use this system are very important in terms of ensuring the current state, usefulness and continuation of this environment. From this point of view, the purpose of the study is to examine the effect of the use of the Educational Information Network (EBA) of teachers in primary schools on the educational process, according to the opinions of classroom teachers who work in school primary schools affiliated to the Ministry of Education in Sapanca district of Sakarya province.

\section{Methodology}

Phenomenology design was used in the study. The phenomenology pattern aims at "focusing on the phenomena that we are aware of but do not have an in-depth and detailed understanding".

In the study, the working group consists of 30 classroom teachers working in the Sapanca district of Sakarya province. The study aimed to provide diversity by reaching out to classroom teachers working in different schools in the creation of a working group.

The interview form was used as a data collection tool in the study. At the preparatory stage of the interview questions, six open-ended questions that would best express the related sub-problems by examining the literature were prepared by the researcher. Open-ended research questions "provide the researcher with the opportunity to address the phenomenon he wants to study with a flexible and open-ended approach" (Yıldırım and Şimşek, 2008).

The data obtained from the interviews were analyzed by descriptive and content analysis methods. With the descriptive analysis method, the data are summarized and interpreted according to the previously identified themes.

\section{Results, conclusion and suggestions}

According to the opinions of the classroom teachers participating in the study, the result was that the EBA was used in all courses at most. The opinions of the classroom teachers participating in the study also showed that EBA 
was used during live lessons for distance learning every weekday. According to the opinions of the classroom teachers who participated in the study, it was seen that the EBA offers students the opportunity to reach different resources thanks to the rich content it provides and is useful in this aspect. According to the opinions of the classroom teachers participating in the study, it was stated as a solution proposal that connection and infrastructure problems frequenlty experienced during the use of EBA should be fixed. It was also determined that problems with the Internet and connection were the most common when students fully participated in the distance learning process, and families acted indifferently in this regard. The classroom teachers participating in the study made suggestions regarding the infrastructure related to distance learning activities implemented in the covid-19 process, planning, the content presented, and EBA implementation. 